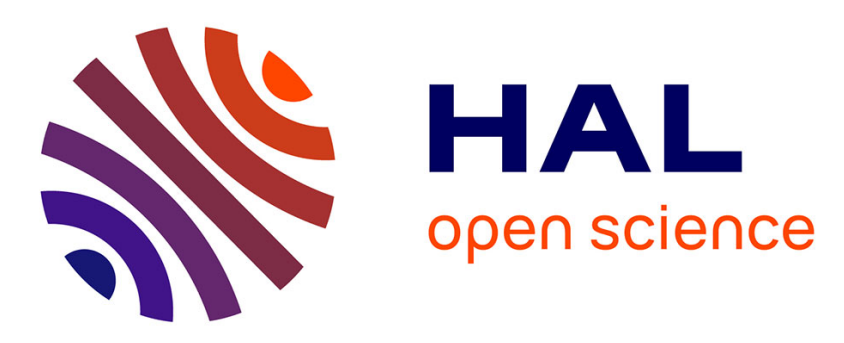

\title{
Synthesis of In-House Produced Calibrated Silver Phosphate with a Large Range of Oxygen Isotope Compositions
}

Christophe Lécuyer, François Fourel, Magali Seris, Romain Amiot, Jean Goedert, Laurent Simon

\section{To cite this version:}

Christophe Lécuyer, François Fourel, Magali Seris, Romain Amiot, Jean Goedert, et al.. Synthesis of In-House Produced Calibrated Silver Phosphate with a Large Range of Oxygen Isotope Compositions. Geostandards and Geoanalytical Research, 2019, 43 (4), pp.681-688. 10.1111/ggr.12285 . hal-02991841

\section{HAL Id: hal-02991841 \\ https://hal.science/hal-02991841}

Submitted on 17 Nov 2020

HAL is a multi-disciplinary open access archive for the deposit and dissemination of scientific research documents, whether they are published or not. The documents may come from teaching and research institutions in France or abroad, or from public or private research centers.
L'archive ouverte pluridisciplinaire HAL, est destinée au dépôt et à la diffusion de documents scientifiques de niveau recherche, publiés ou non, émanant des établissements d'enseignement et de recherche français ou étrangers, des laboratoires publics ou privés.

\section{(c)(1)}

Distributed under a Creative Commons Attribution| 4.0 International License 
1 Synthesis of In-House Made Calibrated Silver Phosphate in a Large Range of Oxygen

2 Isotope Compositions

3

4

5

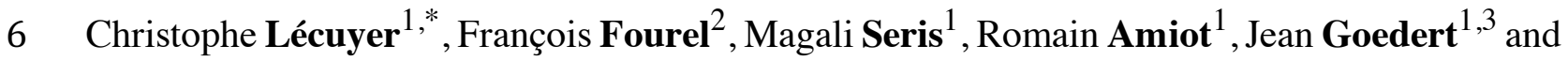
$7 \quad$ Laurent Simon $^{2}$

8

9

10

$11{ }^{1}$ LGL-TPE, UMR 5276, CNRS, Université Claude Bernard Lyon 1, 69622 Villeurbanne,

12 France

13 2LEHNA, UMR 5023, CNRS, Université Claude Bernard Lyon 1, ENTPE, 69622

14 Villeurbanne, France

$15{ }^{3}$ PACEA, UMR 5199, CNRS, Université de Bordeaux, Bâtiment B18, Allée Geoffroy Saint-

16 Hilaire, CS 50023, FR-33615 Pessac, France

17

18 *corresponding author. E-mail : christophe.lecuyer@univ-lyon1.fr

19

20

21 
23 Abstract - The large range of stable oxygen isotope values of phosphate-bearing minerals and 24 dissolved phosphate of inorganic or organic origin requires the availability of in-house made 25 calibrated silver phosphate of which isotopic ratios must closely bracket those of studied samples. We propose a simple protocol to synthesize $\mathrm{Ag}_{3} \mathrm{PO}_{4}$ in a wide range of oxygen isotope compositions based on the equilibrium isotopic fractionation factor and the kinetics and temperature of isotopic exchange in the phosphate-water system. $\mathrm{Ag}_{3} \mathrm{PO}_{4}$ crystals are obtained from $\mathrm{KH}_{2} \mathrm{PO}_{4}$ that is dissolved in water of known oxygen isotope composition. Isotopic exchange between dissolved phosphate and water takes place at a desired and constant temperature into pyrex tubes that are placed in a high precision oven for run-times defined by the user. Samples are withdrawn at desired times, quenched in cold water, and precipitated as $\mathrm{Ag}_{3} \mathrm{PO}_{4}$. We provide a calculation sheet that computes the $\delta^{18} \mathrm{O}$ of precipitated $\mathrm{Ag}_{3} \mathrm{PO}_{4}$ as a

34 function of time, temperature and $\delta^{18} \mathrm{O}$ of both reactants $\mathrm{KH}_{2} \mathrm{PO}_{4}$ and $\mathrm{H}_{2} \mathrm{O}$ at $\mathrm{t}=0$. Predicted oxygen isotope compositions of synthesized silver phosphate range from -7 to $+31 \%$ VSMOW

36 for a temperature range comprised between $110^{\circ} \mathrm{C}$ and $130^{\circ} \mathrm{C}$ and a range of water $\delta^{18} \mathrm{O}$ from -20 to $+15 \%$ o VSMOW.

Keywords: oxygen isotopes, isotopic fractionation, kinetics, silver phosphate, internal reference 
42 Résumé - La large gamme de $\delta^{18} \mathrm{O}$ des minéraux phosphatés et de phosphates dissous d'origine

43 inorganique ou organique nécessite l'existence d' $\mathrm{Ag}_{3} \mathrm{PO}_{4}$ calibré dont les rapports isotopiques

44 doivent encadrer les échantillons étudiés. Nous proposons un protocole simple pour synthétiser

$45 \mathrm{Ag}_{3} \mathrm{PO}_{4}$ dans une large gamme de compositions isotopiques. Ce protocole repose sur les

46 fractionnements isotopiques à l'équilibre et les températures et cinétiques d'échange isotopique

47 dans le système phosphate-eau. Les cristaux d' $\mathrm{Ag}_{3} \mathrm{PO}_{4}$ sont obtenus à partir de $\mathrm{KH}_{2} \mathrm{PO}_{4}$ dissous

48 dans une eau de $\delta^{18} \mathrm{O}$ connu. Les échanges isotopiques entre le phosphate dissous et l'eau ont

49 lieu à une température constante dans des tubes en pyrex placés dans une étuve thermo-régulée

50 pour des durées de réactions définies par l'opérateur. Les échantillons sont retirés en temps

51 voulu, trempés dans de l'eau froide, et précipités sous la forme de cristaux de phosphate

52 d'argent. Nous fournissons une « feuille Excel» qui calcule le $\delta^{18} \mathrm{O}$ d' $\mathrm{Ag}_{3} \mathrm{PO}_{4}$ précipité en

53 fonction du temps, de la température et des $\delta^{18} \mathrm{O}$ de $\mathrm{KH}_{2} \mathrm{PO}_{4}$ et $\mathrm{H}_{2} \mathrm{O}$ au temps $\mathrm{t}=0$. Les $\delta^{18} \mathrm{O}$

54 prédits pour $\mathrm{Ag}_{3} \mathrm{PO}_{4}$ varient de -7 à $+31 \%$ o VSMOW pour une gamme de températures

55 comprises entre $110^{\circ} \mathrm{C}$ et $130^{\circ} \mathrm{C}$ et une gamme de $\delta^{18} \mathrm{O}$ de l'eau de -20 to $+15 \%$ VSMOW.

57 Mots-clés: isotopes de l'oxygène, fractionnement isotopique, cinétique, phosphate d'argent,

58 référence interne

59

\section{Introduction}

During the past decades, the rise of automated devices coupled to mass spectrometers operating in continuous flow or in dual-inlet mode resulted in an explosive growth of the 
number of data published in the scientific fields exploiting the stable isotope ratios of organic and inorganic compounds. Consequently, there is an increasing use and need for developing inhouse made material calibrated against certified reference materials. Moreover, a large range of isotopic compositions is highly desirable to bracket the expected compositions of the studied sample collection as well as to be able to perform a two-point calibration, which is required for the acquisition of high-quality data.

In Earth and Archaeological Sciences, to only mention the most concerned research fields, the ${ }^{18} \mathrm{O} /{ }^{16} \mathrm{O}$ ratio of the phosphate radical $\left(\mathrm{PO}_{4}{ }^{3-}\right)$ is now widely used to reconstruct the paleoclimates of the Earth (Fricke and O’Neil, 1996; Kolodny and Raab, 1988; Amiot et al., 2004; Joachimski et al., 2012; Goedert et al., 2017), the thermophysiology and ecology of extinct vertebrates (Barrick and Showers, 1994; Fricke and Rogers, 2000; Amiot et al., 2006; Tütken and Vennemann, 2009; Bernard et al., 2010; Rey et al., 2018), the source and recycling of dissolved phosphate in natural waters (Markel et al., 1994; McLaughlin et al., 2006; Pistocchi et al., 2017) as well as the diet and living environment of past human populations (White et al., 1998; Evans and Chenery, 2006; Touzeau et al., 2013; Lightfoot and O'Connell, 2016; Pellegrini et al., 2016). The most common way to determine the ${ }^{18} \mathrm{O} /{ }^{16} \mathrm{O}$ ratio of the phosphate radical is to isolate it as silver phosphate $\left(\mathrm{Ag}_{3} \mathrm{PO}_{4}\right)$ crystals through a wet chemistry procedure (Crowson et al., 1991). Then they are pyrolyzed in the presence of graphite at high temperature to produce either $\mathrm{CO}_{2}$ or $\mathrm{CO}$ analysed either off-line or on-line with an isotopic ratio mass spectrometer (O’Neil et al., 1994; Lécuyer et al., 1998; 2007; Fourel et al., 2011). Fluorination technique has also been proven to be a precise and accurate technique that allowed the first determination of the $\delta^{18}$ OSMOW of the Miocene Florida phosphorite SRM 120c (Lécuyer et al., 1993). Whatever the considered research field, the $\delta^{18} \mathrm{O}$ of calcium phosphate minerals (e.g. 
86 biogenic, magmatic or hydrothermal apatite) and dissolved phosphate $\left(\mathrm{H}_{2} \mathrm{PO}_{4}{ }^{-}, \mathrm{HPO}_{4}{ }^{2-}, \mathrm{PO}_{4}{ }^{3-}\right.$

87 ) range worldwide from about a few per mil up to values close to $30 \%$. Indeed, high-

88 temperature apatites of magmatic or hydrothermal origin have $\delta^{18} \mathrm{O}$ ranging from 6 to $11 \%$

89 Sun et al., 2016). Concerning soils and their connected aquatic environments (rivers, ponds,

90 lakes), dissolved phosphate also displays a large range of oxygen isotope compositions

91 comprised between 8\%o and 25\%o (Markel et al., 1994; Gruau et al., 2005; Angert et al., 2012;

92 Davies et al., 2014; Tamburini et al., 2014; Pistocchi et al., 2017; Granger et al., 2017; Bauke

93 et al., 2018). In the case of dissolved phosphate being isotopically equilibrated with ambient

94 water through biological recycling (Longinelli et al., 1976; Liang and Blake, 2009; Chang and

95 Blake, 2015; von Sperber et al., 2017), it is expected to have $\delta^{18} \mathrm{O}$ that range from 6\%o (high-

latitude freshwater environments) to $\approx 20 \%$ for seawater and to $\approx 22 \%$ for low-latitude

freshwater environments in agreement with the available isotopic fractionation equations

(Kolodny et al., 1983; Lécuyer et al., 2013). In the case of biogenic apatites, their $\delta^{18} \mathrm{O}$ values

99

100

101

102

103

104

105

106

107

108

range from a few $\%$ for vertebrates drinking highly ${ }^{18} \mathrm{O}$-depleted waters $\left(\delta^{18} \mathrm{O}\right.$ as low as $-20 \%$ )

relative to SMOW (high-altitude or high-latitude environments; e.g. Rey et al., 2018) up to about 30\% for vertebrates living in arid environments (Lécuyer et al., 1999a).

So far, researchers were using the Florida phosphorite SRM 120c, for which a consensual $\delta^{18}$ OSMOW value of $21.7 \pm 0.2 \%$ (VSMOW) was only admitted these last years.

Indeed, Chenery et al. (2010) proposed a comparable value of $21.7 \pm 0.7 \%$ after a 6 -month period of repeated measurements of SRM 120c calibrated against NBS 127 barium sulfate, which is consistent with the average value of published data for SRM 120c $(21.5 \pm 0.5 \%$ o analyzed in different laboratories (Chenery et al., 2010). Thereafter, Halas et al. (2011) confirmed the absence of any sizable isotopic fractionation effect during the conversion of 
110 laboratory calibrations. It is also worthy to note that Vennemann et al. (2002) proposed a 111 significantly higher value of $22.5 \%$ for SRM 120c. But later on, in a communication given at 112 'IsoPhos' meeting in Ascona, Switzerland, Vennemann (2012) concluded that the most accurate 113 value for SRM $120 \mathrm{c}$ is likely close to $21.7 \%$. This value of $21.7 \pm 0.2 \%$ of for SRM $120 \mathrm{c}$ is now 114 widely accepted as exemplified by the recent study published by Huang et al. (2018). It has also 115 to be pointed out that an isotopic ratio of $21.7 \pm 0.16 \%$ o for SRM $120 \mathrm{c}$ was determined for the 116 first time by using quantitative fluorination 25 years ago (Lécuyer et al., 1993). Nevertheless, 117 it must be underlined that the Florida phosphorite SRM 120c is a compositional, not an isotopic 118 international reference, hence its oxygen isotope ratio has never been officially certified. In 119 order to comply with the IUPAC recommendations (Brandt et al., 2014), a two-point calibration 120 can also be performed with NBS 127, which is a barium sulfate calibrated reference material 121 for oxygen isotopes $\left(\delta^{18} \mathrm{O}=9.3 \%\right.$ VSMOW), as we proceeded in some recent papers (e.g. Rey

122 et al., 2018; Goedert et al., 2018). However, we underline that NBS 127 is a different matrix, 123 i.e. a barium sulfate instead of a silver phosphate, a chemical difference that needs to be taken 124 into account during calibration procedures even though the recently developed "purge-and125 trap" technology was able to overcome this pitfall as shown by Fourel et al. (2011). Moreover, 126 the stock of NBS 127 international reference hosted by the IAEA is now exhausted, thus 127 seriously reducing the possibility of calibrating the oxygen isotope composition of solid 128 matrices. Therefore, the need for alternative calibrated material is becoming critical. Here, we propose a simple and cheap protocol to synthesize silver phosphate in a wide 130 range $(\approx 35 \%$ ) of oxygen isotope compositions based on thermodynamic properties of the 131 phosphate-water system, more specifically the equilibrium isotopic fractionation factor and the 132 kinetics and temperature of isotopic exchange according to the data published by Lécuyer et al. 133 (1999b). Beyond the theoretical considerations, an "Excel calculation sheet" is provided as a 
134 supplementary material. This calculation sheet allows the $\delta^{18} \mathrm{O}$ of precipitated $\mathrm{Ag}_{3} \mathrm{PO}_{4}$ to be 135 predicted by tuning various parameters such as the temperature of oxygen isotope exchange, 136 the duration of the reaction and the isotopic compositions of reactants.

137

138

140

141

142

143

144

145

146

147

148

149

150

151 natural freshwater it is either $\mathrm{H}_{2} \mathrm{PO}_{4}{ }^{-}$or $\mathrm{HPO}_{4}{ }^{2-}$. Lécuyer et al. (1999b) performed kinetics and 152 isotopic experiments at a $\mathrm{pH}$ close to 5 for which $\mathrm{H}_{2} \mathrm{PO}_{4}{ }^{-}$was almost the only species present

153 in solution (Figure 1). During first-order kinetics of reaction, the rate of isotopic exchange can 154 be quantified by considering $f$ as follows,

\section{Theoretical background}

\subsection{First-order kinetics of isotopic exchange between dissolved phosphate and water} The most common $\mathrm{pH}$-dependent speciation of phosphorus in aqueous solution of low ionic strength are (1) the dihydrogen phosphate ion $\left(\mathrm{H}_{2} \mathrm{PO}_{4}^{-}\right),(2)$ the hydrogen phosphate ion $\left(\mathrm{HPO}_{4}{ }^{2-}\right)$, and (3) the phosphate ion $\left(\mathrm{PO}_{4}{ }^{3-}\right)$ according to the three following chemical equilibria at $25^{\circ} \mathrm{C}$ (Zeebe and Wolf-Gladrow, 2001; Figure 1):

$$
\begin{aligned}
& -\mathrm{H}_{3} \mathrm{PO}_{4} \Leftrightarrow \mathrm{H}_{2} \mathrm{PO}_{4}{ }^{-}+\mathrm{H}^{+} \quad\left(\mathrm{pK}_{\mathrm{A} 1}=1.9\right) \\
& -\mathrm{H}_{2} \mathrm{PO}_{4}{ }^{-} \Leftrightarrow \mathrm{HPO}_{4}{ }^{2-}+\mathrm{H}^{+} \quad\left(\mathrm{pK}_{\mathrm{A} 2}=6.1\right) \\
& -\mathrm{HPO}_{4}{ }^{2-} \Leftrightarrow \mathrm{PO}_{4}{ }^{3-}+\mathrm{H}^{+} \quad\left(\mathrm{pK}_{\mathrm{A} 3}=8.9\right)
\end{aligned}
$$

For seawater $(\mathrm{pH} \approx 7.6$ to 8.4$)$, the dominant species is $\mathrm{HPO}_{4}{ }^{2-}$ while in the case of 


$$
f=1-\exp (-k t)=\frac{\delta^{18} O\left(\mathrm{PO}_{4}\right)_{i}-\delta^{18} O\left(\mathrm{PO}_{4}\right)_{t}}{\delta^{18} O\left(\mathrm{PO}_{4}\right)_{i}-\delta^{18} O\left(\mathrm{PO}_{4}\right)_{e}}
$$

157

158

159

160

161

162

163

164

165

166 found a strong temperature dependence of the rate constant $\mathrm{k}$ :

176

177 molecules, while $\mathrm{k}$ is the rate constant $\left(\mathrm{s}^{-1}\right)$ of the isotopic reaction:

$$
k=A \cdot \exp \left(-\frac{E_{a}}{R T}\right)
$$
$\delta^{18} \mathrm{O}\left(\mathrm{PO}_{4}\right)_{\mathrm{e}}$

\subsubsection{The rate constant $k$}

$$
\log (\mathrm{k})=12.35 \pm 0.63-6.98 \pm 0.24\left(10^{3} \mathrm{~T}^{-1}\right)
$$

which is the mole fraction of exchanged isotopes between the phosphate ions and water

with A being the Arrhenius pre-exponential factor, $\mathrm{E}_{\mathrm{a}}$ the activation energy $\left(\mathrm{kJ} \cdot \mathrm{mol}^{-1}\right)$ of the isotopic reaction, $\mathrm{R}$ the universal gas constant, $\mathrm{T}$ the absolute temperature $(\mathrm{K}), \mathrm{t}$ the time $(\mathrm{s}), \delta^{18} \mathrm{O}\left(\mathrm{PO}_{4}\right)_{\mathrm{i}}$ the oxygen isotope composition of the reactant at $\mathrm{t}=0, \delta^{18} \mathrm{O}\left(\mathrm{PO}_{4}\right)_{\mathrm{t}}$ the oxygen isotope composition of $\mathrm{H}_{2} \mathrm{PO}_{4}{ }^{-}$at any time $\mathrm{t}$ during the course of the isotopic reaction, and $\delta^{18} \mathrm{O}\left(\mathrm{PO}_{4}\right)_{e}$ the oxygen isotope composition of $\mathrm{H}_{2} \mathrm{PO}_{4}{ }^{-}$at isotopic equilibrium with $\mathrm{H}_{2} \mathrm{O}$. Note that when $\mathrm{t}=0 ; \mathrm{f}=0$ and $\delta^{18} \mathrm{O}\left(\mathrm{PO}_{4}\right)_{\mathrm{t}}=\delta^{18} \mathrm{O}\left(\mathrm{PO}_{4}\right)_{\mathrm{i}}$ while when $\mathrm{t} \rightarrow \infty ; \mathrm{f} \rightarrow 1$ and $\delta^{18} \mathrm{O}\left(\mathrm{PO}_{4}\right)_{\mathrm{t}}=$

\subsection{Experimental determination of thermodynamic variables $\left(k, E_{a}\right.$ and $\left.\alpha\right)$}

Lécuyer et al. (1999b) performed a best fit of their data with the Arrhenius law and 
A convenient way to report graphically the rate of isotopic exchange against time is to rewrite equation (4) as follows:

$$
\ln (1-f)=-k t
$$

183

$$
t=\frac{0.693}{k}
$$

\subsubsection{The activation energy $E_{a}$ of the reaction} equation (6) combined to equation (5).

\subsubsection{The fractionation coefficient $\alpha$ between $\mathrm{H}_{2} \mathrm{PO}_{4}{ }^{-}$and $\mathrm{H}_{2} \mathrm{O}$}


201 the following isotopic exchange equation:

202

203

$$
\mathrm{H}_{2} \mathrm{P}^{16} \mathrm{O}_{4}^{-}+\mathrm{H}_{2}{ }^{18} \mathrm{O} \quad \leftrightarrow \mathrm{H}_{2} \mathrm{P}^{18} \mathrm{O}_{4}^{-}+\mathrm{H}_{2}{ }^{16} \mathrm{O}
$$

204

Rearranging the terms in equation (9), the equilibrium constant or isotopic fractionation

factor called $\alpha$, which is determined for a given temperature $\mathrm{T}$, is expressed as follows:

207

208

$$
\alpha_{\left(H_{2} P O_{4}^{-}-H_{2} O\right)}=\frac{\left[\frac{18 O}{16 O}\right]_{H_{2} P O_{4}^{-}}}{\left[\frac{18 O}{16 O}\right]_{H_{2} O}}
$$

It is worthy to note that this temperature-dependent fractionation factor $\alpha$ must be

211 independent from the isotopic compositions of both reactants according to Northrop and

212 Clayton (1966). Lécuyer et al. (1999b) determined experimentally $\alpha\left(\mathrm{H}_{2} \mathrm{PO}_{4}{ }^{-}-\mathrm{H}_{2} \mathrm{O}\right)$ in the 213 temperature range 75 to $135^{\circ} \mathrm{C}$ :

$$
10^{3} \ln \alpha\left(\mathrm{H}_{2} \mathrm{PO}_{4}{ }^{-}-\mathrm{H}_{2} \mathrm{O}\right)=18.35 \pm 0.37\left(10^{3} \mathrm{~T}^{-1}\right)-32.29 \pm 1.01
$$

\section{Application to the synthesis of silver phosphate of known oxygen isotope ratio}

\subsection{Experimental protocol of silver phosphate precipitation}

We present a protocol of silver phosphate precipitation from a highly soluble salt in

221 water (solubility $=25 \mathrm{~g} .100 \mathrm{~mL}^{-1}$ at $25^{\circ} \mathrm{C}$; Lide, 2005) such as the potassium dihydrogen 
222 phosphate $\mathrm{KH}_{2} \mathrm{PO}_{4}$ (Lécuyer et al., 1999b). An aliquot of $50 \mathrm{mg}$ of pure high-grade (> 99.5

$223 \mathrm{wt} \%$ ) Sigma-Aldrich ${ }^{\mathrm{TM}}$ synthetic $\mathrm{KH}_{2} \mathrm{PO}_{4}$ is dissolved in $35 \mathrm{~mL}$ of deionized water of known

224 oxygen isotope composition. The resulting aqueous solutions have a concentration of $1 \mathrm{~g} . \mathrm{L}^{-1}$

$225\left(10.6 \mathrm{mmol} . \mathrm{l}^{-1}\right)$ of phosphate ions with a $\mathrm{pH}$ of 5 at ambient temperature. It is important to note

226 that the amount of oxygen in water is much higher than in the pool of dissolved phosphate

227 (oxygen molar ratio between $\mathrm{H}_{2} \mathrm{O}$ and $\mathrm{KH}_{2} \mathrm{PO}_{4} \approx 5000$ ), consequently the change in the oxygen

228 isotope composition before and after equilibrium is not detectable with respect to the analytical

229 uncertainties $\left(1 \sigma=0.05 \%\right.$ for the $\delta^{18} \mathrm{O}$ of $\left.\mathrm{H}_{2} \mathrm{O}\right)$. The solutions are transferred into Ace

230 Glass $^{\mathrm{TM}}$ pyrex tubes sealed with a threaded teflon plug. Each set of tubes for a given temperature

231 is placed in a high precision oven for run-times defined by the user. Samples are withdrawn at

232 desired times and quenched in cold water to room temperature within a few minutes. Each

233 sample of dissolved phosphate is quantitatively precipitated as silver phosphate (chemical

234 yields are close to 100\%) according to the protocol determined by Firsching (1961), which

235 means that all the dissolved phosphate species $\left(\approx \mathrm{H}_{2} \mathrm{PO}_{4}^{-}\right)$, are converted into $\mathrm{Ag}_{3} \mathrm{PO}_{4}$. For a

236 chemical yield of $100 \%$, the expected amount of silver phosphate is close to $150 \mathrm{mg}$. Running

237 an experiment batch with ten Ace Glass ${ }^{\mathrm{TM}}$ pyrex tubes at the same time ensures the production

238 of about $1.5 \mathrm{~g}$ of silver phosphate crystals of predicted oxygen isotope composition.

\subsection{Oxygen isotope analysis of silver phosphate}

Oxygen isotope compositions are measured using a high-temperature pyrolysis technique involving a VarioPYROcube ${ }^{\mathrm{TM}}$ elemental analyzer (EA) interfaced in continuous

244 flow (CF) mode to an Isoprime ${ }^{\mathrm{TM}}$ isotopic ratio mass spectrometer (IRMS) (EA-Py-CF-IRMS 
technique (Lécuyer et al., 2007; Fourel et al., 2011) at the University Claude Bernard Lyon 1.

246 For each sample, 5 aliquots of $300 \mu \mathrm{g}$ of $\mathrm{Ag}_{3} \mathrm{PO}_{4}$ are mixed with $300 \mu \mathrm{g}$ of pure carbon black

247 powder and loaded in silver foil capsules. Pyrolysis is performed at a temperature of $1450^{\circ} \mathrm{C}$.

248 Measurements are calibrated against the SRM 120c (natural Miocene phosphorite from Florida) 249 and the NBS 127 (barium sulfate, $\mathrm{BaSO}_{4}: \delta^{18} \mathrm{O}=9.3 \%$ VSMOW). The $\delta^{18} \mathrm{O}$ of SRM 120c is 250 fixed at 21.7\% (VSMOW) according to Lécuyer et al. (1993) who determined this value by 251 fluorinating silver phosphate crystals $(n=25,1 \sigma=0.16)$ at $600^{\circ} \mathrm{C}$ for 12 hours and calibrated 252 the oxygen isotope ratios with the calibrated reference material NBS 28 quartz $(9.5 \pm 0.2 \% 0$, and 253 measurement standards that are the "Snowbird" quartz $(16.1 \pm 0.1 \%$ ) and the tholeiitic basaltic 254 glass standard CIRCE $93(5.6 \pm 0.1 \%$ ).

255

\subsection{Predicted oxygen isotope composition of synthesized silver phosphate}

According to equation (4), for any temperature $\mathrm{T}, \mathrm{k}$ and $\delta^{18} \mathrm{O}\left(\mathrm{PO}_{4}\right)_{\mathrm{e}}$ are calculated, $\mathrm{t}$ and $\delta^{18} \mathrm{O}\left(\mathrm{PO}_{4}\right)_{\mathrm{i}}$ are measured, which means that $\delta^{18} \mathrm{O}\left(\mathrm{PO}_{4}\right)_{\mathrm{t}}$ can be predicted as follows:

$\delta^{18} O\left(P_{4}\right)_{t}=\delta^{18} O\left(P_{4}\right)_{i}-\left\{\delta^{18} O\left(P O_{4}\right)_{i}-\delta^{18} O\left(P O_{4}\right)_{e}\right\}\{1-\exp (-k t)\}$

$264130^{\circ} \mathrm{C}$. Indeed, below a temperature of $110^{\circ} \mathrm{C}$, kinetics of reaction is so slow that significant

265 isotopic exchange takes months, or even years when temperature is below $100^{\circ} \mathrm{C}$. Then, above 266 a temperature of $130^{\circ} \mathrm{C}$, the Ace Glass ${ }^{\mathrm{TM}}$ pyrex tubes sealed with a threaded teflon plug could 267 start to leak, leading to a shift of the initial oxygen isotope ratio of water. Finally, we provide an "Excel calculation sheet" (Supplementary File) that automatically computes the oxygen 
269 isotope composition of the precipitated silver phosphate depending on time $t$ and temperature

$270 \mathrm{~T}$ of isotopic exchange as well as the oxygen isotope compositions of reactants $\mathrm{KH}_{2} \mathrm{PO}_{4}$ and

$271 \mathrm{H}_{2} \mathrm{O}$ at $\mathrm{t}=0$. Predicted oxygen isotope compositions of synthesized silver phosphate range from

$272-7$ to $+31 \%$ V VSMOW for a temperature range comprised between $110^{\circ} \mathrm{C}$ and $130^{\circ} \mathrm{C}$ and a range

273 of water $\delta^{18} \mathrm{O}$ from -20 to $+15 \%$ VSMOW (Figure 2). For example, we have provided a 274 calculation table (Supplementary File) showing a possible tuning of the parameters described 275 above to obtain silver phosphate crystals with a $\delta^{18} \mathrm{O}$ value (\%o VSMOW) that mimics that 276 certified for the NBS 127 barium sulfate international reference. In order to further demonstrate the efficiency of this method, we analysed the oxygen

278 isotope compositions of three silver phosphates with expected $\delta^{18} \mathrm{O}$ values ranging from about $279+10$ to $+22 \%$ VSMOW (Table 1 ), which cover the most common range of documented $\delta^{18} \mathrm{O}$ 280 values for natural dissolved phosphate and apatites. We reported the measured $\delta^{18} \mathrm{O}$ values as 281 a function of the expected ones and we obtained a strong linear correlation with a slope close 282 to $1(\mathrm{a}=1.032 \pm 0.029)$ and an intercept close to $0(\mathrm{~b}=-0.794 \pm 0.466)$ (Figure 3$)$. Within this 283 isotopic variation range of $12 \%$, the calculated standard error is $0.24 \%$, which is comparable 284 to the error associated with the admitted $\delta^{18} \mathrm{O}$ value of SRM 120c. Therefore, we show that this method is suitable to produce robust in-house made calibrated $\mathrm{Ag}_{3} \mathrm{PO}_{4}$ for the oxygen isotope analysis of phosphatic compounds.

\subsection{Potential application to the sulfate-water system}


291 barium sulfate of known oxygen isotope composition. Indeed, the required thermodynamic

292 properties such as the rate constant $\mathrm{k}$, the activation $\mathrm{E}_{\mathrm{a}}$ and the $\mathrm{T}$-dependent isotopic

293 fractionation factor $\alpha$ have been determined by Chiba and Sakai (1985). The oxygen isotope

294 measurement of sulfates, whatever their natural or anthropogenic origin, could be very useful

295 to trace the mechanisms of their formation. For instance, sulfates may form in the atmosphere

296 from the oxidation of sulfur dioxide by hydroxyl radicals, hydrogen peroxide or ozone. Sulfates may also result from a high-temperature oxidation to produce sulfur trioxide during combustion processes before being ultimately hydrated to form sulfuric acid. Various oxygen isotope fractionations could be associated with those chemical reactions, requiring the production of calibrated barium sulfate with different $\delta^{18}$ Ovsmow values.

\section{Conclusions}

The protocol we developed in this study is based on the equilibrium isotopic 305 fractionation factor $\alpha$, the kinetics $\mathrm{k}$ and temperature $\mathrm{T}$ of isotopic exchange in the dissolved 306 phosphate-water system. It offers the possibility to produce in a reasonable amount of time (a 307 few days or a couple of weeks) about $1.5 \mathrm{~g}$ (the equivalent of 1,000 measurements) of silver 308 phosphate of known oxygen isotope composition. Moreover, the tuning of some parameters 309 (time and temperature of isotopic exchange and the compositions of reactants) allows the synthesis of silver phosphate within a large range $(\approx 35 \%)$ of oxygen isotope ratios that match

311 the documented natural variability for both phosphate-bearing minerals and dissolved 312 phosphate of organic or inorganic origin. 
314 Acknowledgements - this study has been founded by CNRS and IUF (CL).

315 
References

318

Amiot R., Lécuyer C., Buffetaut E., Escarguel G., Fluteau F. and Martineau F. (2006)

Oxygen isotopes from biogenic apatites suggest widespread endothermy in Cretaceous

dinosaurs. Earth and Planetary Science Letters, 246, 41-54.

322

Amiot R., Lécuyer C., Buffetaut E., Fluteau F., Legendre S. and Martineau F. (2004)

Latitudinal temperature gradient during the Cretaceous Upper Campanian-Middle

Maastrichtian: $\delta^{18} \mathrm{O}$ record of continental vertebrates. Earth and Planetary Science Letters,

226, 255-272.

Angert A., Weiner T., Mazeh S. and Sternberg M. (2012)

Soil phosphate stable oxygen isotopes across rainfall and bedrock gradients. Environmental

Science and technology, 46, 2156-2162.

Barrick R.E. and Showers W.J. (1994)

Thermophysiology of Tyrannosaurus rex: evidence from oxygen isotopes. Science, 265, 222224.

Bauke S.L., Sperber (von) C., Tamburini F., Gocke M.I., Honermeier B., Schweitzer K.,

\section{Baumecker M., Don A., Sandhage-Hofmann A. and Amelung W. (2018)}

338 Subsoil phosphorus is affected by fertilization regime in long-term agricultural experimental trials. European Journal of Soil Science, 69, 103-112. 
Bernard A., Lécuyer C., Vincent P., Amiot R., Bardet N., Buffetaut E., Cuny G., Fourel

F., Martineau F., Mazin J.-M., and Prieur A. (2010)

343 Regulation of body temperature by some Mesozoic marine reptiles. Science, 328, 1379-1382.

Brandt W., Coplen T.B., Vogl J., Rosner M. and Prohaska T. (2014)

Assessment of international reference materials for isotope-ratio analysis (IUPAC Technical

Report). Pure and Applied Chemistry, 86, 425-467.

Chang S.J. and Blake R.E. (2015)

Precise calibration of equilibrium oxygen isotope fractionations between dissolved phosphate and water from 3 to $37^{\circ} \mathrm{C}$. Geochimica et Cosmochimica Acta, 150, 314-329.

Strontium and stable isotope evidence for diet and mobility in Roman Gloucester, UK. Journal of Archaeological Science, 37, 150-163.

356

Chiba H. and Sakai H. (1985)

Oxygen isotope exchange rate between dissolved sulfate and water at hydrothermal temperatures. Geochimica et Cosmochimica Acta, 49, 993-1000. 
366 Phosphate oxygen isotopes within aquatic ecosystems: Global data synthesis and future 367 research priorities. Science of the Total Environment, 496, 563-575.

368

369 Evans J.A., Chenery C.A. and Fitzpatrick A.P. (2006)

370 Bronze age childhood migration of individuals near Stonehenge, revealed by strontium and 371 oxygen isotope tooth enamel analysis. Archaeometry, 48, 309-321.

372

373

Firsching F.H. (1961)

374 Precipitation of silver phosphate from homogeneous solution. Analytical Chemistry, 33, 873375874.

376

Fourel F., Martineau F., Lécuyer C., Kupka H.J., Lange L., Ojeimi C. and Seed M. (2011)

${ }^{18} \mathrm{O} /{ }^{16} \mathrm{O}$ ratios measurements of inorganic and organic materials by EA-Pyrolysis-IRMS continuous flow techniques. Rapid Communications in Mass Spectrometry, 25, 2691-2696.

380

Fricke H.C. and Rogers R.R. (2000)

Multiple taxon-multiple locality approach to providing oxygen isotope evidence for warm-

383 blooded theropod dinosaurs. Geology, 28, 799-802.

384

385 Fricke H.C. and O'Neil J.R. (1996)

386 Inter- and intra-tooth variation in the oxygen isotope composition of mammalian tooth enamel 387 phosphate: implications for palaeoclimatological and palaeobiological research. 388 Palaeogeography, Palaeoclimatology, Palaeoecology, 126, 91-99. 
391 Segade U. and Lécuyer C. (2017)

392 Miocene (Burdigalian) seawater and air temperatures estimated from the geochemistry of 393 vertebrate remains from the Aquitaine Basin, France. Palaeogeography, Palaeoclimatology, 394 Palaeoecology, 481, 14-28.

Goedert J., Lécuyer C., Amiot R., Wang X.,Cui L., Cuny G., Douay G., Fourel F., Simon

L., Steyer S. and Zhu M. (2018)

Euryhaline ecology of early tetrapods revealed by stable isotopes. Nature, 558, 68-72.

399

Granger S.J., Harris P., Peukert S., Guo R., Tamburini F., Blackwell M.S., Howden

N.J.K. and McGrath S. (2017)

402

Phosphate stable oxygen isotope variability within a temperate agricultural 403 soil. Geoderma, 285, 64-75. eutrophication research? Water Research, 39, 232-238.

Halas S., Skrzypek G., Meier-Augenstein W., Pelc A. and Kemp H.F. (2011) 
415 Did climate changes trigger the Late Devonian Kellwasser Crisis? Evidence from a high-

416 resolution conodont $\delta^{18} \mathrm{OPO}_{\mathrm{PO}}$ record from South China. Earth and Planetary Science Letters, $417495,174-184$.

419 Joachimski M.M., Lai X., Shen S., Jiang H., Luo G., Chen B., Chen J. and Sun Y. (2012)

420 Climate warming in the latest Permian and the Permian-Triassic mass extinction. Geology, 40, 421 195-198.

423 Kolodny Y., Luz B. and Navon O. (1983)

Oxygen isotope variations in phosphate of biogenic apatites, I. Fish bone apatite - rechecking the rules of the game. Earth and Planetary Science Letters, 64, 398-404.

Kolodny Y. and Raab M. (1988)

Oxygen isotopes in phosphatic fish remains from Israel; paleothermometry of tropical 64, 59-67.

Lécuyer C., Amiot R., Trotter J. and Touzeau A. (2013)

433 Calibration of the phosphate $\delta^{18} \mathrm{O}$ paleothermometer with the calcium carbonate-water oxygen 434 isotope fractionation equations. Chemical Geology, 347, 217-226.

436 Lécuyer C., Fourel F., Martineau F., Amiot R., Bernard A., Daux V., Escarguel G. and 437 Morrison J. (2007) 
438 High-precision determination of ${ }^{18} \mathrm{O} /{ }^{16} \mathrm{O}$ ratios of silver phosphate by EA-pyrolysis-IRMS

439 continuous flow technique. Journal of Mass Spectrometry, 42, 36-41.

440

441 Lécuyer C., Grandjean P., Mazin J.-M. and De Buffrénil V. (1999a)

442 Oxygen isotope compositions of reptile bones and teeth: a potential record of terrestrial and 443 marine paleoenvironments, in: E. Hoch, A.K. Brantsen (Eds.), Secondary Adaptation to Life

444 in Water II, University of Copenhagen (Denmark), Geologisk Museum, p. 33.

445

446 Lécuyer C., Grandjean P. and Sheppard S.M.F. (1999b)

447 Oxygen isotope exchange between dissolved phosphate and water at temperatures temperatures $448<135^{\circ} \mathrm{C}$ : inorganic versus biological fractionations. Geochimica et Cosmochimica Acta, 63, $449855-862$.

450

451 Lécuyer C., Grandjean P., Barrat J.-A., Nolvak J., Emig C.C., Paris F. and Robardet M., 4521998.

$453 \delta^{18} \mathrm{O}$ and REE contents of phosphatic brachiopods: a comparison between modern and lower 454 Paleozoic populations. Geochimica et Cosmochimica Acta, 62, 2429-2436.

455

456 Lécuyer C., Grandjean P., O'Neil J.R., Cappetta H. and Martineau F. (1993)

457 Thermal excursions in the ocean at the Cretaceous-Tertiary boundary (northern Morocco):

$458 \delta^{18} \mathrm{O}$ record of phosphatic fish debris. Palaeogeography Palaeoclimatology Palaeoecology, 459 105, 235-243.

460

$461 \quad$ Liang Y. and Blake R.E. (2009) 
462 Compound-and enzyme-specific phosphodiester hydrolysis mechanisms revealed by $\delta^{18} \mathrm{O}$ of 463 dissolved inorganic phosphate: Implications for marine $\mathrm{P}$ cycling. Geochimica et 464 Cosmochimica Acta, 73, 3782-3794.

466 Lide D.R. (2005)

467 CRC Handbook of Chemistry and Physics 86th Edition 2005-2006. CRC Press, Taylor \& 468 Francis, Boca Raton, FL 2005, p. 4-79.

Lightfoot E. and O’Connell T.C. (2016)

471 On the use of biomineral oxygen isotope data to identify human migrants in the archaeological 472 record: intra-sample variation, statistical methods and geographical considerations. PLOS 473 ONE, DOI:10.1371/journal.pone.0153850.

Longinelli A., Bartelloni M. and Cortecci G. (1976)

The isotopic cycle of oceanic phosphate, I. 1976. Earth and Planetary Science Letters, 32, 389-392.

Markel D., Kolodny Y., Luz B. and Nishri A. (1994)

480 Phosphorus cycling and phosphorus sources in Lake Kinneret: Tracing by oxygen isotopes in 481 phosphate. Israelian Journal of Earth Sciences, 43, 165-178.

483 McLaughlin, K., Kendall C., Silva S.R., Young, M. and Paytan A. (2006).

484 Phosphate oxygen isotope ratios as a tracer for sources and cycling of phosphate in North San 485 Francisco Bay, California. Journal of Geophysical Research, 111, G03003, 486 doi:10.1029/2005JG000079. 
Northrop D.A. and Clayton R.N. (1966)

Oxygen isotope fractionations in systems containing dolomite. Journal of Geology, 74, 174196.

O'Neil J.R., Roe L.J., Reinhard E. and Blake R.E. (1994)

493 A rapid and precise method of oxygen isotope analysis of biogenic phosphate. Israelian Journal of Earth Sciences, 43, 203-212.

Pellegrini M., John Pouncett J., Jay M., Pearson M.P. and Richards M.P. (2016)

Tooth enamel oxygen "isoscapes" show a high degree of human mobility in prehistoric Britain.

Scientific Reports, 6, 34986; doi: 10.1038/srep34986.

Pistocchi C., Tamburini F., Gruau G., Ferhi A., Trevisan D. and Dorioz J.-M. (2017)

Tracing the sources and cycling of phosphorus in river sediments using oxygen isotopes:

Methodological adaptations and first results from a case study in France. Water Research, 111, 346-356.

504

Rey K., Day M.O., Amiot R., Goedert J., Lécuyer C., Sealy J. and Rubidge B.S. (2018)

506 Stable isotope record implicates aridification in late Capitanian mass extinction. Gondwana Research, 59, 1-8.

508

509 Sun Y., Wiedenbeck M., Joachimski M.M., Beier C., Kemner F. and Weinzierl C. (2016)

510 Chemical and oxygen isotope composition of gem-quality apatites: Implications for oxygen 511 isotope reference materials for secondary ion mass spectrometry (SIMS). Chemical Geology, 
440, 164-178.

513

514 Tamburini F., Pfahler V., von Sperber C., Frossard E. and Bernasconi S.M. (2014)

515 Oxygen isotopes for unraveling phosphorus transformations in the soil-plant system: A 516 review. Soil Science Society of America Journal, 78, 38-46.

517

Touzeau A., Blichert-Toft J., Amiot R., Fourel F., Martineau F., Cockitt J., Hall K.,

Flandrois J.-P. and Lécuyer C. (2013)

520 Egyptian mummies record increasing aridity in the Nile valley from 5,500 to 1,500 B.P. Earth

521 Planetary and Science Letters, 375, 92-100.

522

Tütken T. and Vennemann T. (2009)

524 Stable isotope ecology of Miocene large mammals from Sandelzhausen, southern Germany.

525 Paläontologische Zeitschrift, 83, 207-226.

526

Vennemann T.W., Fricke H.C., Blake R.E., O’Neil J.R. and Colman A. (2002)

Oxygen isotope analysis of phosphates: a comparison of techniques for analysis of $\mathrm{Ag}_{3} \mathrm{PO}_{4}$.

Chemical Geology, 185, 321-336.

530

531 Vennemann T. W. (2012)

532 Further comparison of methods of oxygen isotope analysis of phosphates and standards use.

533 IsoPhos 2012 Annual Meeting, 25-29 June, Asconda, Switzerland.

535 von Sperber C., Lewandowski H., Tamburini F., Bernasconi S.M., Amelung W. and 536 Frossard E. (2017) 
537 Kinetics of enzyme-catalysed oxygen isotope exchange between phosphate and water revealed 538 by Raman spectroscopy. Journal of Raman Spectroscopy, 48, 368-373.

539

540 White C.D., Spence M.W., Stuart-Williams H.L.Q. and Schwarcz H.P. (1998)

541 Oxygen isotopes and the identification of geographical origins: The Valley of Oaxaca versus

542 the Valley of Mexico. Journal of Archaeological Science, 25, 643-655.

543

544 Zeebe R. E. and Wolf-Gladrow D. (2001)

$545 \mathrm{CO}_{2}$ in Seawater: Equilibrium, Kinetics, Isotopes. Elsevier Oceanography Series, 65, pp. 346,

546 Amsterdam, 2001

547 


\section{Table captions:}

550

551 Table 1: Comparison between measured $\left(\delta^{18} \mathrm{O}_{\text {measured }}\right)$ and predicted $\left(\delta^{18} \mathrm{O}_{\text {predicted }}\right)$ oxygen

552 isotope compositions of silver phosphate samples. The $\delta^{18} \mathrm{O}_{\text {predicted values have been calculated }}$

553 by using equation (6) and (12) knowing the temperature $\mathrm{T}$ and duration $\mathrm{t}$ of isotope exchange

554 reaction along with the initial compositions of dissolved phosphate $\delta^{18} \mathrm{O}\left(\mathrm{PO}_{4}\right)_{i}$ and water

$555 \delta^{18} \mathrm{O}\left(\mathrm{H}_{2} \mathrm{O}\right)_{i}$ reactants. The $\delta^{18} \mathrm{O}_{\text {measured values have been obtained by using the analytical }}$

556 protocol presented in sections 3.1 and 3.2.

557 
Figure captions:

561 Figure 1: $\mathrm{pH}$-dependent speciation of dissolved phosphate in aqueous solution according to

562 Zeebe and Wolf-Gladrow (2001).

563

564 Figure 2: Oxygen isotope composition of dissolved phosphate (or precipitated silver phosphate)

565 as a function of time $\mathrm{t}$ (in days) of isotopic exchange for a temperature $\mathrm{T}$ of $110^{\circ} \mathrm{C}$ and a $\delta^{18} \mathrm{O}$

566 of water of $+15 \%$ (blue curve) and for a temperature $\mathrm{T}$ of $130^{\circ} \mathrm{C}$ and a $\delta^{18} \mathrm{O}$ of water of $-20 \%$ o

567 (red curve). After no more than 1 month of isotopic exchange between dissolved phosphate and

568 water, the precipitated silver phosphate crystals reach the isotopic equilibrium with water and

569 have $\delta^{18} \mathrm{O}$ values close to $+31 \%$ VSMOW (blue curve) and -7\% VSMOW (red curve), 570 respectively.

571 For instance, the $\delta^{18} \mathrm{O}$ of $\mathrm{H}_{2} \mathrm{O}(\mathrm{i})$ of $+15 \%$ VSMOW can be obtained by collecting $1 \mathrm{~L}$

572 of residual water obtained by evaporation at ambient temperature $\left(\approx 20^{\circ} \mathrm{C}\right)$ under a laminar flow

573 hood of $50 \mathrm{~L}$ of deionized water with an initial $\delta^{18} \mathrm{O}$ of $-10.5 \%$ of which the ultimate source is

574 the Rhône river. The $\delta^{18} \mathrm{O}$ of $\mathrm{H}_{2} \mathrm{O}(\mathrm{i})$ of $-20 \%$ VSMOW can be obtained in Lyon, France, by 575 collecting frozen atmospheric vapour trapped inside a freezer working at a temperature of $57680^{\circ} \mathrm{C}$.

578 Figure 3: Linear regression between the oxygen isotope compositions of measured and predicted $\delta^{18} \mathrm{O}$ values of three samples of synthesized silver phosphate. A slope of $1.032 \pm 0.029$ and an intercept of $-0.794 \pm 0.466$ with a $\mathrm{R}^{2}$ of 0.999 indicate a good fit between these two 
581 variables. The standard error of $0.24 \%$ measures the robustness of the isotopic composition of

582 the precipitated silver phosphate that can be used as in-house made calibrated material.

583 
585 Supplementary File:

586

587 Table: "Excel calculation sheet" that computes the oxygen isotope composition of the 588 precipitated silver phosphate depending on time $t$ and temperature $\mathrm{T}$ of isotopic exchange along 589 with the oxygen isotope compositions of reactants $\mathrm{KH}_{2} \mathrm{PO}_{4}$ and $\mathrm{H}_{2} \mathrm{O}$ at $\mathrm{t}=0$. The provided 590 example provided shows a possible tuning of the parameters described above to obtain silver

591 phosphate crystals with a $\delta^{18} \mathrm{O}$ value (\%o VSMOW) similar to that certified for the NBS 127 592 barium sulfate international reference.

593 Description of column assignment: $\mathrm{C} 0-\mathrm{C} 1=$ temperature $\mathrm{T}$; $\mathrm{C} 2-\mathrm{C} 3=$ rate constant $\mathrm{k}$; $\mathrm{C} 4-\mathrm{C} 5=$ 594 time $\mathrm{t}$; $\mathrm{C} 6=$ fraction $\mathrm{f}$ of isotopic exchange; $\mathrm{C} 7-\mathrm{C} 8=$ oxygen isotope compositions of reactants 595 at $\mathrm{t}=0$; $\mathrm{C} 9-\mathrm{C} 10=$ isotopic fractionation factor $\alpha$ between dissolved phosphate and water; C1159612 oxygen isotope composition of dissolved phosphate at equilibrium at any time t. 


\begin{tabular}{|c|c|c|c|c|c|c|c|}
\hline $\begin{array}{l}\text { Calibrated } \\
\text { Material }\end{array}$ & $\begin{array}{l}\delta^{18} \mathrm{O}(\text { water }) \\
(\% \text { VSMOW })\end{array}$ & $\begin{array}{c}\text { Equilibration } \\
\text { (days) }\end{array}$ & $\begin{array}{c}\delta^{18} \mathrm{O}\left(\mathrm{Ag}_{3} \mathrm{PO}_{4}\right) \text { predicted } \\
(\% \text { VSMOW })\end{array}$ & S.D. & $\begin{array}{c}\delta^{18} \mathrm{O}\left(\mathrm{Ag}_{3} \mathrm{PO}_{4}\right) \text { measured } \\
(\% \text { VSMOW })\end{array}$ & S.D. & $\mathrm{N}$ \\
\hline CAL1 & 7.74 & 37 & 21.68 & 0.54 & 21.66 & 0.10 & 8 \\
\hline CAL3 & -1.18 & 44 & 15.06 & 0.01 & 14.55 & 0.35 & 10 \\
\hline CAL2 & -7.42 & 44 & 9.90 & 0.28 & 9.53 & 0.28 & 6 \\
\hline
\end{tabular}




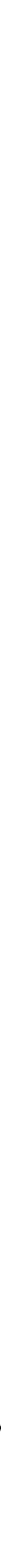




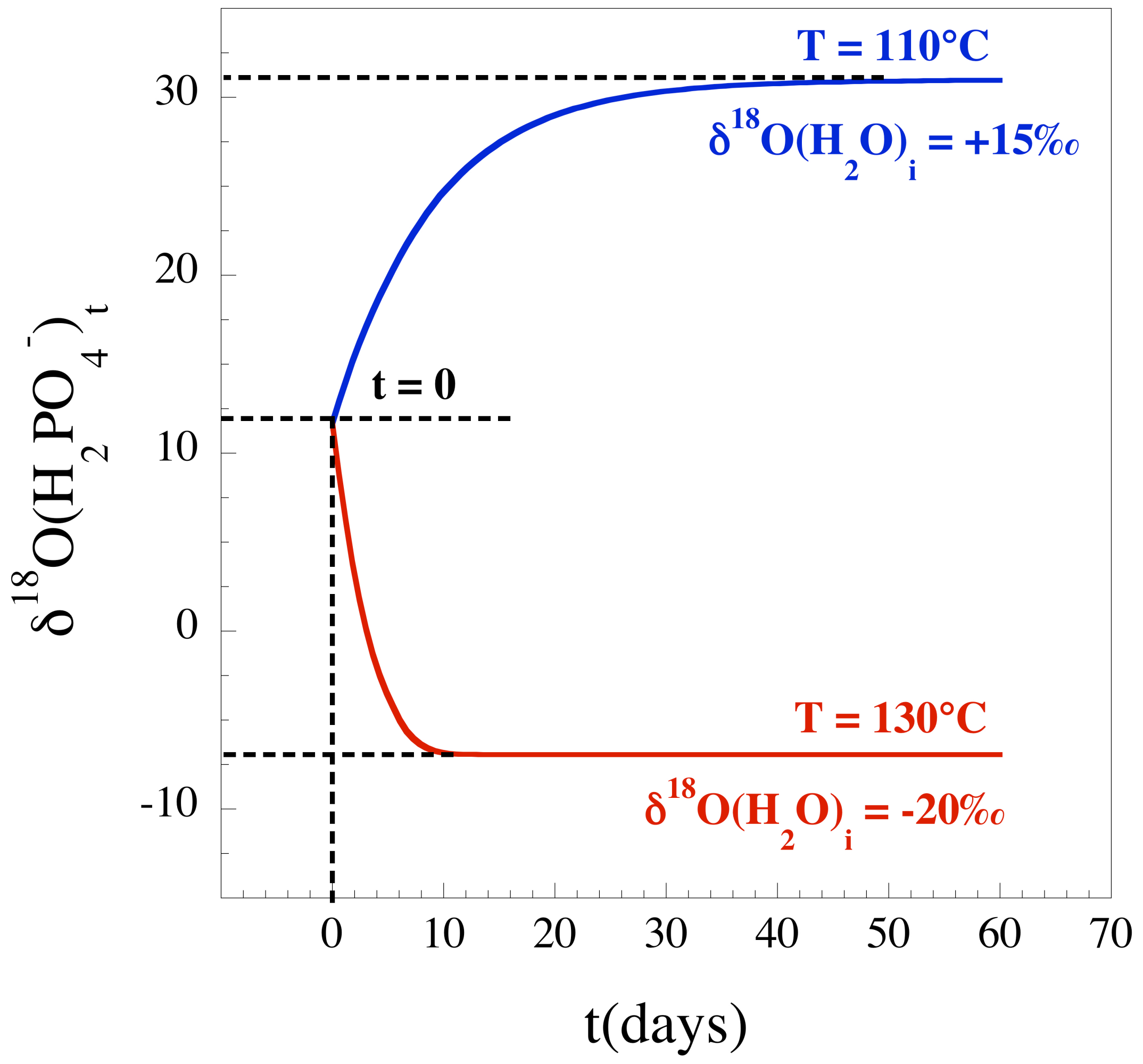




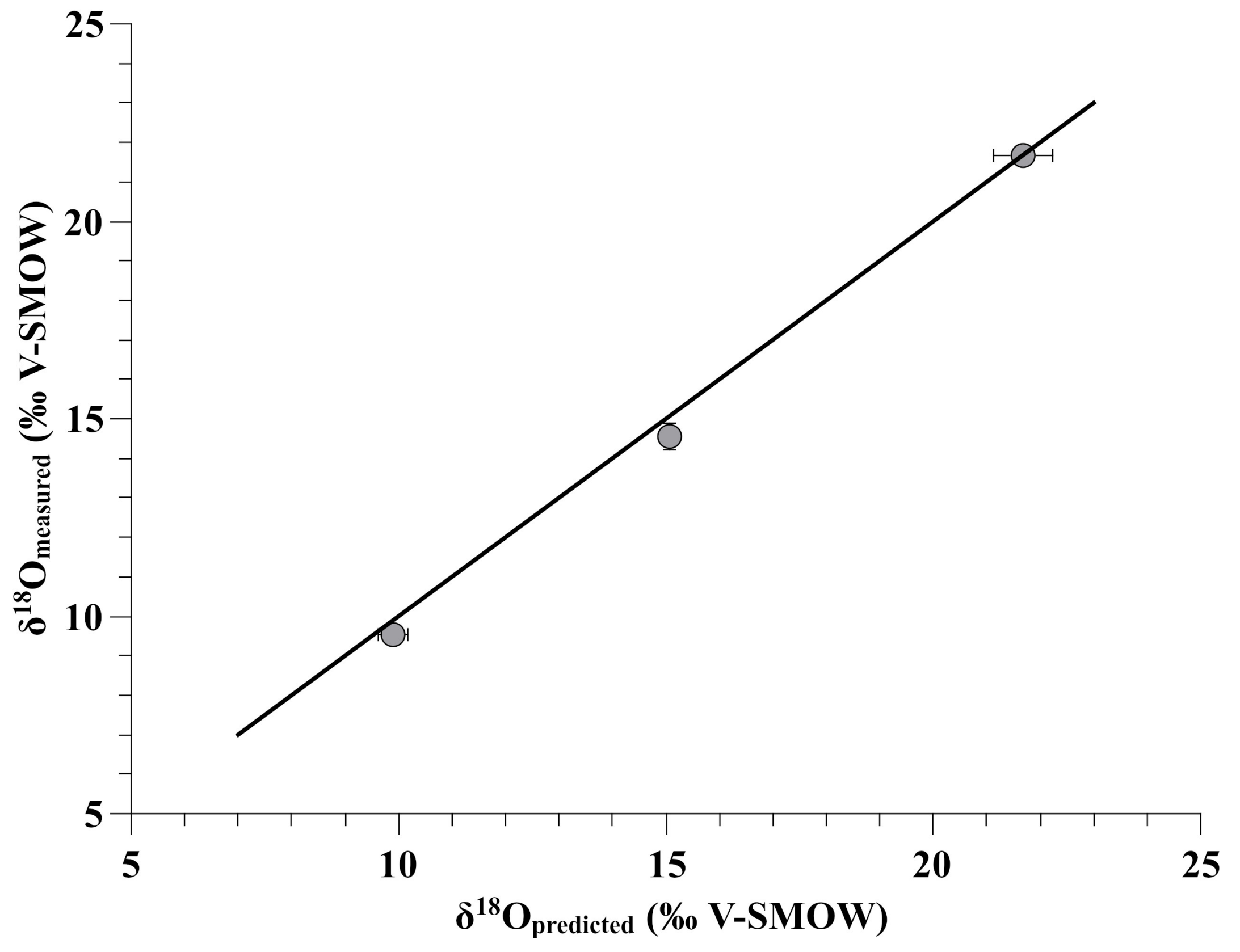

